\title{
Analysis of Source and Use of Working Capital in PT. Sido Muncul, Tbk. (Period 2016-2018)
}

\author{
Menik Tri Wahyuni \\ Department of Management, Faculty of Economics and Business, Narotama University, Indonesia
}

\begin{abstract}
Working capital is a very important part of the company. Working capital should always be available enough to be able to provide maximum benefits and the company's operations can continues. Analysis of source and use of working capital is needed for companies to find out the source of funds and how those fund spent.The purpose of this study is to determine the analysis of sources and uses of working capital of PT Sido Muncul,Tbk in Semarang, and to review the policy of uses working capital of PT Sido Muncul, Tbk in Semarang. This study use dercriptive qualitative method. The result of this research indicate that the source of working capital in 2016 to 2018 is quite good. However, in 2017 and 2018 the use of working capital's company is greater than the source. In 2016 working capital of PT Sido Muncul was increase Rp55.060.000.000. Whereas in 2017 was decrease Rp158.045.000.000 and in 2018 also decreased Rp241.108.000.000. This is due to the high amount of increase in fixed as sets by the company. For investment policies, companies tend to use conservative policies, while for working capital expenditure policies companies tend to use aggressive policies.
\end{abstract}

Keywords: Working capital; investment policy; expenditure policy.

\section{Introduction}

In order to achieve goals, companies must be able to improve the quality and function of their management. This can be seen from the number of companies with similar business fields, which require companies to always increase the value of their company by conducting economic activities that focus on corporate goals and customer satisfaction. . One important part that must be considered is the company's working capital. Companies must be able to manage working capital well so that operational activities can be fulfilled.

To be able to know the financial condition of a company, financial managers must prepare financial statements that can describe various financial transactions which are used to analyze financial statement data. This data is very useful for companies because financial statement analysis can be used to find out the company's financial development which is then used by leaders to make decisions in the future.

One of analysis of financial statements needed is a report on sources and uses of working capital, that is an analysis of where the source of working capital is obtained and the use of the working capital.. Working Capital is an operating fund that must be available sufficiently to be used to pay for raw materials, labor costs, employee salaries and other operating activities that support sales.. This working capital is included in the short-term funding requirement, which is less than 1 (one) year. It is expected that funds released by the company for operating activities will re-enter through sales and can be reused for further operations. So working capital is used continuously as long as the company's activities are still ongoing. In Indonesia, there are many similar companies that are competing to meet people's needs. One of them is the herbal and pharmaceutical industry. The growing community interest in o $\mathrm{n}$ e of the herbal medicine herbal medicine caused many emerging companies seeing opportunities. This also happened to PT

\footnotetext{
* Corresponding author.

E-mail address: meniktriwahyuni@gmail.com (Menik Tri Wahyuni)
} 
Sido Muncul, Tbk.

Working capital of PT Sido Muncul in 2016 to 2018 can be seen in the table 1.

Table 1. Working Capital of PT Sido Muncul in 2016-2018

\begin{tabular}{ccccc}
\hline Components of Financial Statement & 2015 & 2016 & 2017 & 2018 \\
\hline Total Current Assets & $1,707,439$ & $1,794,125$ & $1,628,901$ & $1,547,666$ \\
Total Current Debt & 184,060 & 215,686 & 208,507 & 368,380 \\
Total Net Working Capital & $1,523,379$ & $1,578,439$ & $1,420,394$ & $1,179,286$ \\
\hline
\end{tabular}

Source : Company's Financial Statement

From the table above, it can be seen that working capital in 2016 has increased. But in 2017 and 2018 it has decreased. So that it needs to be analyzed further about the causes of the decline in PT Sido Muncul's working capital in that period.

The objective of this study:

1) To find out the analysis of sources and uses of working capital at PT Sido Muncul in Semarang .

2) To review the policy of using working capital at PT Sido Muncul in Semarang.

\section{Literature Review}

\subsection{Working Capital}

According to Sawir (2001), working capital is the entire current assets owned by the company, or it can also be intended as a fund that must be available to finance the company's daily operations (Wahyuni, 2016).

According to Riyanto (2001), the types of working capital classified by Taylor WB are divided into two, namely (Wahyuni, 2016) :

1) Permanent Working Capital

Working capital that must remain in the company to be able to carry out its functions, or in other words, working capital is continuously needed for expeditious bussiness. Permanent working capital is divided by:
a. Primary Working Capital
b. Normal Working Capital

2) Variable Working Capital

Working capital that is the number fluctuates according to the changing circumstances in the period. Variable working capital can be divided into 3, namely:
a. Seasonal Working Capital
b. Cyclical Working Capital
c. Emergency Working Capital

\subsection{Sources of Working Capital}

According to Riyanto (2009) the sources of working capital can be described as (Sopini \& Trifani, 2017) :

a. Reduced fixed assets

b. Increased long-term debt

c. Increased capital

d. Benefits from company's operations 


\subsection{Use of Working Capital}

According to Sawir (2002) the use of working capital which results in a decrease in working capital namely (Setyo \& Maqsudi, 2016) :

a. Decreased own capital due to loss and privacy by the owner of the company

b. Payment of long-term debts

c. Additions or purchases of fixed assets

\subsection{Report of Source and Use of Working Capital}

Reports of changes of working capital are needed by the company as a basis for planning and managing working capital in the future. The intended report is required to be able to show in detail the increase or decrease in working capital year by year.

According to S. Munawir (2002) argues that: Working capital report is a summary of the results of the company's financial activities in a given period and presents the causes of changes in the company's financial position during the period concerned. (Maswatu, Pelleng, \& Tampi, 2003)

After a change of working capital is analyzed, it will be known that the increase or decrease that occurred. The increase in current assets and a decrease in current debt will be assessed as good if it comes from the company's operating results. But it will be considered less good if it comes from long-term debt. Reports on changes in working capital will show the magnitude of the changes that occur for each element of working capital. While reports of sources and uses of working capital can show the cause of the change in working capital and where the funds come from. Stages or steps in preparing the source report and the use of working capital according to Bambang Riyanto (2001: 355) are as follows(Lisnawati Bahutala, 2014):

a. Compile reports of changes in working capital

b. Group changes in non-current elements accaounts between these two time points into groups that have the effect of enlarging working capital and groups that have the effect of minimizing working capital

c. Grouping elements in statements of retained earnings into groups whose changes have enlarged effects and groups that have the effect of minimizing working capital

d. Based on the above information can be compiled reports on sources and uses of working capital

\subsection{Investment Policy and Working Capital Expenditure}

Working capital policy involves two main questions, namely how much work capital or current assets are right for a company and how to pay for working capital or current assets(Sudana, 2011). According to (Sudana, 2011) policies relating to the size of the amount of investment in working capital are divided into three, namely:
a. Conservative Policy
b. Aggressive Policy
c. Moderate Policy

Working capital spending policy relates to determination types of sources that will be used to buy investment in working capital. . Like working capital investment policies, working capital spending policies are also divided into (Sudana, 2011) :
a. Conservative Policy
b. Aggressive Policy
c. Moderate Policy 


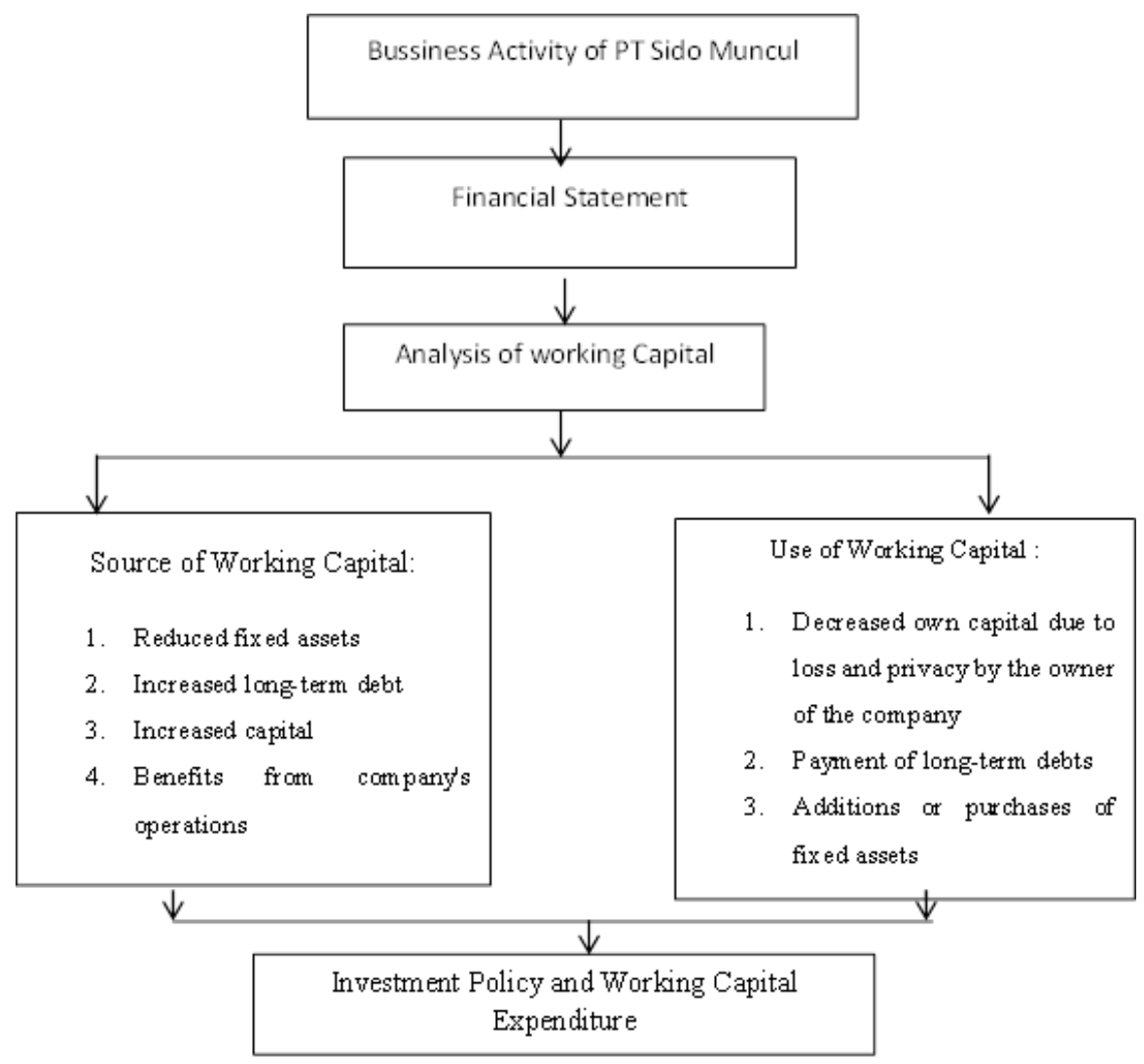

Fig. 1. Conceptual framework

\section{Methods}

\subsection{Research Type}

Research type used in this study is a case study, because this research focuses on one object, namely PT Sido Muncul, Tbk. While the research method used is qualitative descriptive method.

\subsection{Types of Data}

The type of data used in this study is quantitative data. Namely the data obtained in the form of numbers, which consist of PT Sido Muncul's balance sheet financial in 2016 to 2018. And data needed in this study is secondary data. The data to be used is obtained from internet access through the official website of PT. Sido Muncul on March 6, 2019. 


\section{Result and Discussions}

\subsection{Analysis of Changes in Working Capital}

From the table 2, it can be seen that in 2016 Current Assets increased by Rp86,686,000,000, while current liabilities decreased by Rp31,626,000,000. So that means an increase in working capital of IDR 55,060,000,000. The increase in working capital is due to the increase in current assets greater than the amount of the decrease in current debt. The biggest increase in current liabilities came from cash and cash equivalents, which amounted to Rp.160,160,000,000.

Table 2. Report on Changes in Working Capital of PT Sido Muncul Tbk in 2015-2016 (expressed in millions of rupiah)

\begin{tabular}{|c|c|c|c|c|}
\hline \multirow{2}{*}{ Account } & \multirow{2}{*}{2015} & \multirow{2}{*}{2016} & \multicolumn{2}{|c|}{ Working Capital } \\
\hline & & & Increase & Decrease \\
\hline \multicolumn{5}{|l|}{ CURRENT ASSETS } \\
\hline Cash and Cash Equivalent & 836,975 & 997,135 & 160,160 & \\
\hline Time Deposits & 190,000 & 5,000 & & 185,000 \\
\hline Account Receivable & 347,730 & 387,218 & 39,488 & \\
\hline Inventories & 264,982 & 317,082 & 52,100 & \\
\hline Prepaid Taxes & 47,972 & 51,003 & 3,031 & \\
\hline Advance Payments & 7,175 & 4,108 & & 3,067 \\
\hline Prepaid Expenses & 12,605 & 32,579 & 19,974 & \\
\hline Total Current Assets & $1,707,439$ & $1,794,125$ & & \\
\hline \multicolumn{5}{|l|}{ CURRENT LIABILITIES } \\
\hline Trade Payable & 147,753 & 177,864 & & 30,111 \\
\hline Other Payable & 10,532 & 5,459 & 5,073 & \\
\hline Taxes Payable & 21,475 & 27,709 & & 6,234 \\
\hline Acrual Expenses & 3,297 & 2,815 & 482 & \\
\hline Other current liabilities & 1,003 & 1,839 & & 836 \\
\hline Total current liabilities & 184,060 & 215,686 & & \\
\hline Total & & & 280,308 & 225,248 \\
\hline Increase of Working Capital & & & & 55,060 \\
\hline Total & & & 280,308 & 280,308 \\
\hline Working Capital (CA-CL) & $1,523,379$ & $1,578,439$ & & \\
\hline Difference & 55,060 & & & \\
\hline
\end{tabular}

Based on Tables 3, it can be seen that PT Sido Muncul, Tbk in 2017 experienced a decrease in current assets which in 2016 amounted to Rp1,794,125,000,000 and then in 2017 amounted to Rp1,628,901,000,000 resulting in a decrease of 165,224,000,000 while the current debt was at in 2016 amounted to Rp215,686,000,000 and in 2017 amounted to Rp208,507,000,000 resulting in an increase in current debt of Rp.7,179,000,000. This means that the company experienced a decrease in working capital of Rp. 158,045,000,000. This decrease in working capital is due to the high decrease in current assets. The biggest decline came from cash and cash equivalents, namely Rp 94,283,000,000. 
Table 3. Reports on Changes in Working Capital of PT Sido Muncul Tbk in 2016-2017 (Expressed in millions of Rupiah)

\begin{tabular}{|c|c|c|c|c|}
\hline \multirow{2}{*}{ Account } & \multirow{2}{*}{2016} & \multirow{2}{*}{2017} & \multicolumn{2}{|c|}{ Working Capital } \\
\hline & & & Increase & Decrease \\
\hline \multicolumn{5}{|l|}{ CURRENT ASSETS } \\
\hline Cash and Cash Equivalent & 997,135 & 902,852 & & 94,283 \\
\hline Time Deposits & 5,000 & - & & 5,000 \\
\hline Account Receivable & 387,218 & 431,502 & 44,284 & \\
\hline Inventories & 317,082 & 267,915 & & 49,167 \\
\hline Prepaid Taxes & 51,003 & 14,900 & & 36,103 \\
\hline Advance Payments & 4,108 & 3,508 & & 600 \\
\hline Prepaid Expenses & 32,579 & 8,224 & & 24,355 \\
\hline Total Current Assets & $1,794,125$ & $1,628,901$ & & \\
\hline \multicolumn{5}{|l|}{ CURRENT LIABILITIES } \\
\hline Trade Payable & 177,864 & 124,898 & 52,966 & \\
\hline Other Payable & 5,459 & 11,093 & & 5,634 \\
\hline Taxes Payable & 27,709 & 33,644 & & 5,935 \\
\hline Acrual Expenses & 2,815 & 36,730 & & 33,915 \\
\hline Other current liabilities & 1,839 & 2,142 & & 303 \\
\hline Total current liabilities & 215,686 & 208,507 & & \\
\hline Total & & & 97,250 & 255,295 \\
\hline Decrease of Working Capital & & & 158,045 & \\
\hline Total & & & 255,295 & 255,295 \\
\hline Working Capital (CA-CL) & $1,578,439$ & $1,420,394$ & & \\
\hline Difference & & 158,045 & & \\
\hline
\end{tabular}

Based on the table 4, it can be seen that PT Sido Muncul, Tbk experienced 2018 decrease in current assets which in 2017 amounted to Rp1,628,901,000,000 and then in 2018 there were Rp1,547,666,000,000 which decreased by Rp81,235,000,000 while current debt in 2017 amounted to Rp208,507,000,000 and in 2018 amounted to Rp368,380,000,000 resulting in a decrease in current debt of Rp.159,873,000 .000. This means that the company experienced a decrease in working capital of Rp241,108,000,000. The decline in working capital is due to the high value of current assets that have dropped. The biggest decrease came from cash and cash equivalents, which amounted to $\mathrm{Rp} 97,019,000,000$.

Based on the table 5, it can be seen that in 2016 PT Sido Muncul experienced a capital increase employment amounting to Rp55,060,000,000. The increase in working capital is due to the source of working capital greater than its use.

In 2016 it can be seen that the company purchases fixed assets of Rp89,354,000,000 which of course will be used for the development of the company. This policy is considered very effective because this year the company has a fairly high source of working capital, one of which comes from the increase in capital that is quite high, which is Rp. $159,571,000,000$. So that if the company makes an asset purchase, it will not interfere with the company's financial condition or working capital. 
Table 4 Reports on Changes in Working Capital of PT Sido Muncul Tbk in 2017-2018 (expressed in millions of rupiah)

\begin{tabular}{|c|c|c|c|c|}
\hline \multirow{2}{*}{ Account } & \multirow{2}{*}{2017} & \multirow{2}{*}{2018} & \multicolumn{2}{|c|}{ Working Capital } \\
\hline & & & Increase & Decrease \\
\hline \multicolumn{5}{|l|}{ CURRENT ASSETS } \\
\hline Cash and Cash Equivalent & 902,852 & 805,833 & & 97,019 \\
\hline Account Receivable & 431,502 & 414,903 & & 16,599 \\
\hline Inventories & 267,915 & 311,193 & 43,278 & \\
\hline Prepaid Taxes & 14,900 & - & & 14,900 \\
\hline Advance Payments & 3,508 & 6,767 & 3,259 & \\
\hline Prepaid Expenses & 8,224 & 8,970 & 746 & \\
\hline Total Current Assets & $1,628,901$ & $1,547,666$ & & \\
\hline \multicolumn{5}{|l|}{ CURRENT LIABILITIES } \\
\hline Trade Payable & 124,898 & 181,657 & & 56,759 \\
\hline Other Payable & 11,093 & 7,622 & 3,471 & \\
\hline Taxes Payable & 33,644 & 80,323 & & 46,679 \\
\hline Acrual Expenses & 36,730 & 85,830 & & 49,100 \\
\hline Other current liabilities & 2,142 & 12,948 & & 10,806 \\
\hline Total current liabilities & 208,507 & 368,380 & & \\
\hline Total & & & 50,754 & 291,862 \\
\hline Decrease of Working Capital & & & 241,108 & \\
\hline Total & & & 291,862 & 291,862 \\
\hline Working Capital (CA-CL) & $1,420,394$ & $1,179,286$ & & \\
\hline Difference & & 241,108 & & \\
\hline
\end{tabular}

Analysis of Source and Use of Working Capital

Table 5 Source Report and Use of Working Capital of PT Sido Muncul in 2016 (expressed in millions of rupiah)

\begin{tabular}{|l|r|l|r|}
\hline \multicolumn{2}{|c|}{ Sources } & \multicolumn{2}{c|}{ Usage } \\
\hline Increased pension benefit obligations & 473 & Decreased tax liability & 167 \\
\hline Increased capital & 159,571 & Increased advance of fix asset & 20,634 \\
\hline Decreased other fixed assets & 13,262 & Increased deferred tax assets & 8,091 \\
\hline & & Increased fixed assets & 89,354 \\
\hline Total & 173,306 & Total & $\mathbf{1 1 8 , 2 4 6}$ \\
\hline Increase of Working Capital & & & $\mathbf{5 5 , 0 6 0}$ \\
\hline Total & $\mathbf{1 7 3 , 3 0 6}$ & & $\mathbf{1 7 3 , 3 0 6}$ \\
\hline
\end{tabular}

From the table 6, it is shown that in 2017 PT Sido Muncul experienced a decrease in working capital of Rp158,045,000,000. This decrease in working capital is caused by the use of working capital which is greater than the source of working capital. 
Table 6. Source and Use Report of PT Sido Muncul's Working Capital in 2017 (expressed in millions of Rupiah)

\begin{tabular}{|l|r|l|r|}
\hline \multicolumn{2}{|c|}{ Sources } & \multicolumn{2}{c|}{ Usage } \\
\hline ncreased employee benefit obligations & 30,979 & Increased Advance Payments in Fix Assets & 128,922 \\
\hline Increased capital & 137,980 & Increased deferred tax assets & 37,735 \\
\hline Increased tax liabilities & 8,804 & Increased fixed assets & 163,949 \\
\hline & & Increased other fixed assets & 5,202 \\
\hline Total & $\mathbf{1 7 7 , 7 6 3}$ & Total & $\mathbf{3 3 5 , 8 0 8}$ \\
\hline Decrease of Working Capital & $\mathbf{1 5 8 , 0 4 5}$ & & $\mathbf{3 3 5 , 8 0 8}$ \\
\hline Total & $\mathbf{1 7 7 , 7 6 3}$ & & \\
\hline
\end{tabular}

In 2017, it can be seen that the company purchased fixed assets of Rp.163,949,000,000. This policy is considered inaccurate because of the high number of fixed asset purchases, while the source of working capital has a difference that is not too far from the previous year. This is the reason for the decline in working capital. So that it is feared that the purchase of fixed assets will disrupt the company's finances.

Table 7. Source and Use Report of PT Sido Muncul's Working Capital in 2018 (expressed in millions of rupiah)

\begin{tabular}{|l|r|l|r|}
\hline \multicolumn{2}{|c|}{ Sources } & \multicolumn{2}{c|}{ Usage } \\
\hline Increased employee benefit obligations & 11,030 & Increased deferred tax assets & 13,532 \\
\hline Increased capital & 6,749 & Increased fixed assets & 338,186 \\
\hline Increased deferred tax assets & 1,778 & Increased other fixed assets & 67,479 \\
\hline Decreased advance fix asset & 158,532 & & \\
\hline Total & $\mathbf{1 7 8 , 0 8 9}$ & Total & $\mathbf{4 1 9 , 1 9 7}$ \\
\hline Decrease of Working Capital & $\mathbf{2 4 1 , 1 0 8}$ & & \\
\hline Total & $\mathbf{1 7 8 , 0 8 9}$ & & $\mathbf{4 1 9 , 1 9 7}$ \\
\hline
\end{tabular}

From the table 7, it can be seen that in 2018 PT Sido Muncul experienced a decrease in working capital of Rp241,108,000,000. The decrease in working capital is caused by the use of working capital which is greater than the source of working capital. In 2018, it was shown that the highest decrease in working capital was due to fixed asset purchases, which amounted to Rp338,186,000,000. When compared with the previous year fixed asset purchases in 2018, almost twice as large as in 2017. While the largest source of working capital came from the reduction of fixed assets up to Rp158 .532,000,000. This policy is considered to be less appropriate for the company because it causes a significant reduction in working capital and is feared to disrupt the company's financial performance

\section{Investment Policy and Working Capital Expenditures}

The working capital investment policy relates to the amount of effective working capital for the company and how to use the working capital. According to the research table above, it can be seen that in providing working capital in 2016, 2017 and 2018, companies tend to use conservative policies. Where the size of the company's current assets is quite high. This policy will cause a high level of company liquidity, meaning that the company will be able to fulfill its current obligations. However, this causes a low level of profitability, because the amount of current assets is large. The spending policy is related to determining the type of source that will pay for working capital investment. According to the research table above, it can be seen that in spending working capital, in 2016, 2017 and 2018, companies tend to use Aggressive policies. This means that in financing current assets, the company uses a short-term source of funds for all variable current assets and some permanent current assets. This can be seen from the high amount of current debt, which causes a decrease in working capital. 


\section{Conclusions}

The conclusion of the research conducted by the author on PT Sido Muncul is as follows:

1) The source of working capital of PT Sido Muncul from 2016 to 2018 can be said to be quite good. The biggest source of working capital in PT Sido Muncul in 2016 and 2017 comes from increasing capital. Whereas in 2018 the largest source of working capital came from the reduction in fixed assets advances. Other sources come from the increase in employee benefits obligations, increased tax obligations, and reduced other fixed assets. Whereas the biggest use of working capital in 2016, 2017 and 2018 from the increase in fixed assets. This shows that every year the company seeks to expand its business activities to increase profits. However, in 2017 and 2018 PT Sido Muncul has experienced a considerable decline in working capital. This is due to the high use of the company's working capital in the last two years.

2) Investment policy at PT Sido Muncul, Tbk uses conservative policies. This means that companies tend to maintain substantial current assets. So this company will be able to fulfill its short-term obligations. Whereas for the working capital spending policy of PT Sido Muncul Tbk, it tends to use aggressive policies. This means that all variable current assets and some permanent current assets are financed using short-term funding sources.

\section{References}

Lisnawati Bahutala, J. S. (2014). Sumber dan Penggunaan Modal Kerja Pada PT Kentucky Fried Chicken (KFC) Periode 2009-2012. Ekonomi, Bisnis Dan Manajemen, 2(4), 309-319.

Maswatu, A. G., Pelleng, F., \& Tampi, D. (2003). Analisis Sumber Dan Penggunaan Modal Kerja Pada PT. Bank Tabungan Negara, (Persero) Tbk. Cab. Manado, 1-12.

Setyo, T., \& Maqsudi, A. (2016). Analisis Sumber dan Penggunaan Modal Kerja Untuk Mengukur Kinerja Keuangan pada PT. Timah (Persero) Tbk (Pengamatan di BEI Periode Tahun 2009-2012), 1(April), 109-118.

Sopini, P., \& Trifani, C. Y. (2017). Analisis Sumber dan Penggunaan Modal Kerja Pada Mini Market Pelangi Jambi, l(1), 197-212.

Sudana, I. M. (2011). Kebijakan Investasi dan Pembelanjaan Modal Kerja. In Manajemen Keuangan Perusahaan (pp. 196-199). Jakarta: Erlangga.

Wahyuni, D. (2016). Analisis Efisiensi Penggunaan Modal Kerja Pada UD. Arifa Souvenir Jombang, 10(2). Retrieved from https://ejournal.stiedewantara.ac.id/index.php/001/article/download/57/46 